\title{
Hybridization of Poplars in the Central Cherno- zem Region of Russia
}

\author{
Anatoly Tsarev ${ }^{1},{ }^{3}$, Georg von Wühlisch², Raisa Tsareva ${ }^{1}$
}

\author{
${ }^{1}$ All-Russian Research Institute of Forest Tree Genetics, Breeding and Biotechnology, Russia \\ 2 Johann-Heinrich von Thünen-Institute, Institute for Forest Genetics, Großhansdorf, Germany \\ ${ }^{3}$ Petrozavodsk State University, Russia
}

* Corresponding author: A. Tsarev, E-mail: anatolytsa@gmail.com

\begin{abstract}
Hybridization offers huge potential in domesticating species. Poplars are important for wood production and also ornamental uses. Only two poplar parents can generate by hybridization more than 500,000 different offspring phenotypes. The article reviews some international results and presents some Russian results of poplar hybridization, emphasizing the Central Chernozem Region of the European part of Russia. During 60 years 736 crosses were realized, resulting in 54,000 hybrid seedlings. In different field trials 243 superior clones were selected. For practical operations twelve cultivars of the most productive and frost resistant poplar hybrids were selected. Three of them are now approved as varieties by the state registration authorities. In order to mitigate the risks from unforeseen disease, injury or other adverse factors in defined environments several cultivars with close economic value but with different genetic composition should be available.
\end{abstract}

Keywords: poplars, hybridization, field testing, cultivars, growth indices, Central Chernozem Region of Russia

\section{Introduction}

Hybridization is one method to raise heterozygosity and the genotypic composition of living organisms.

Among woody species, this method is used most widely in poplar breeding. Poplars are the fastest growing tree species of the temperate zone. They are considered as the most promising forest trees for wood production, land reclamation, greening afforestations, and other applications.

K. Yanchevsky (1904) carried out the first hybridization experiments on detached flowering branches and received hybrid seeds in the Salicaceae. The first practically significant results on poplar hybridization were obtained by $A$. Henry in 1912 (Pauley, 1949) in the UK by producing the first $P$. $\times$ generosa Henry ( $P$. trichocarpa Hooker $\times$ P. deltoides Marshall) individuals.

By the beginning of the forties of the twentieth century 83 hybrid poplars of natural and artificial origin, excluding the USSR, had been realized as a result of intra- and intersectional crosses. Among them, 14 hybrids were Populus $\times$ Populus; 2 Populus $\times$ Tacamahaca; 4 Populus $\times$ Aigeiros; 7 Tacamahaca $\times$ Tacamahaca; 28 Tacamahaca $\times$ Aigeiros and 28 hybrids Aigeiros $\times$ Aigeiros (Pauley, 1949).

The first large poplar hybridization program had been undertaken in the USA by A.B. Stout, R. McKee and E.J. Schreiner. 13,000 hybrid seedlings were obtained, 69 of which were selected as elite, and ten of them received varietal names: Frye, Rumford, Strathglass (all three are P. nigra $\times$ P. laurifolia hybrids), Roxbury (P. nigra $\times P$. trichocarpa), Andover (P. nigra betulifolia $\times P$. trichocarpa), Geneva, Oxford (P. maximowiczii $\times$ P. $\times$ berolinensis), Rochester (P. maximowiczii $\times$ P. nigra plantierensis), Androscoggin (P. maximowiczii $\times$ P. trichocarpa), Maine (P. candicans $\times P . \times$ berolinensis) (Stout, McKee and Schreiner, 1927; Stout and Schreiner, 1933).

The second major program of poplar hybridization was the works of W. von Wettstein $(1941,1942)$, performed in Germany and in Austria since the early thirties (Wright, 1962). Then 
poplar hybridization at a substantial scale engaged breeders in different countries. Only one Institute in Grammont (Belgium) produced 30-40 thousand seedlings annually, 200-300 clones of them were selected and tested (Steenackers, 1969). Achievements were reached in Canada (Heimburger, 1936; Zsuffa et al., 1993), in Italy (Sekawin, 1960, 1971), in Poland (Tyszkiewicz, Chmielewski, 1961; Chmielewski, 1969), in France (Lemoine, 1973), in Germany (von Wühlisch, 2006, 2010; Janßen et al. 2012; Liesebach et al, 2012), in USA (Stanton, 2012, Stanton et al., 2014) and in other countries.

In the Soviet Union, the most widely-known studies were accomplished by A.V. Albensky (1959), P. L. Bogdanov (1965), A. M. Berezin (1939), A.S. Yablokov (1956, 1963), I.A. Kazartsev (1956), G.P. Ozolin (1962), S.P. Ivannikov (1959), N.V. Starova (1980), P.P. Besschetnov (1969), N.A. Konovalov (1963) and others.

The largest series of hybridization work with poplars in the USSR include:

1) The experiments of A.M. Berezin in Ufa (implemented more than 80 different crosses, received more than 80 thousand hybrid seedlings, from which he selected 18 best trees).

2) P.L. Bogdanov in St. Petersburg (160 different crosses, 75 of which were successful, 2500 hybrid seedlings grown, 32 of which were selected, and 4 were recommended for use).

3) P.P. Besschetnov in Alma-Ata (170 different crosses, 26 of which were successful, 1.5 million seedlings grown, 26 selected, 8 recommended for use).

4) N.V. Starova with co-workers in Ukraine (conducted 462 crosses, 600 thousand seedlings received, 900 selected in the elite collection, 12 recommended for use).

A more detailed review of international and Russian experiences in the hybridization of poplars requires a special review. Professor M. M. Veresin from Voronezh Forest-Technical Institute (currently Voronezh State Forest University) initiated the hybridization work with poplars in the Central Chernozem Region of European Russia in the fifties of the twentieth century (Veresin, 1974). These works were continued by scientists of the Central Research Institute of Forest Genetics and Breeding (currently All-Russian Research Institute of Forest Genetics, Breeding and Biotechnology) A.P. Tsarev, V.P. Petrukhnov, R.P. Tsareva, a. o. (Veresin, Tsarev, 1974; Tsarev, 1984, 2013 a, b; Tsareva, 1988; Petrukhnov, 1988; Tsarev, Tsareva, 1990, 2010; Tsarev et al., 2014).

The aim of this paper is to take stock of the hybridization work carried out in the Central Chernozem Region, to present the results, and to introduce the selected promising fast-growing and frost resistant hybrid trees.

\section{Material and Methods}

The poplars used for hybridization were selected in arboretums, clone collections of Voronezh, and surrounding plantations. The best hybrids derived in the pioneering works by forest tree breeders nationally and internationally were employed for hybridizations during 1970-1980. In this series, methods were applied as stated in publications by A.S. Yablokov (1963),
A.V. Albensky (1959), S. S. Pyatnitsky (1961) and M.M. Veresin (1974) with some modification (Tsarev, 1984).

Crossings were carried out in early spring on detached branches. They were placed in saline (white poplars and aspens), or sandy substrate (Eupopulus poplars) during pollination and seed production. The obtained seedlings were planted in soil (1 part of soil, sand, and peat each). When they had reached a height of $6-10 \mathrm{~cm}$ they were transplanted into open ground under a plastic sheet covering.

In the subsequent years, the saplings were field-tested at the permanent sites as follows:

1. In the years after 1951 Professor M.M. Veresin created different collections of hybrid poplar and field tests. Here, two of these will be focused on. One collection was created 1952 in compartment 54 of Pravoberezhny Forest-Division of Educational and Skilled Forest Enterprise of the Voronezh State Forest-Technical University. The soil is dark-grey forest medium loam. Several clones and hybrids of different poplar species were tested in this collection and three hybrid families with 8 to 15 siblings per family. The second poplar collection was created in the upland oak forest on the grounds of wood-decorative nursery "New". The soil is leached chernozem. Here he planted ten elite hybrid seedlings and rooted cuttings of hybrids, including two cloned plants of cultivar E. s. - 38 (elite seedling-38, or 'Voronezh Giant' = 'VGt'). All parents used for crosspollinations were taken from stands of the Chernozem Region.

2. A.P. Tsarev carried out hybridization experiments from 1972 to 1978 . In total, 111 crossing combinations were generated: 3 in 1972, 10 in 1973, 9 in 1974, 29 in 1975, 24 in 1976, 17 in 1977, and 19 in 1978. 12910 seeds were produced in 55 combinations. Of these 2995 seedlings germinated of 42 hybrid combinations. The number of 1-year-old seedlings was 1651 of 31 families.

Between 1977 and 1980 seedlings from 23 hybrid families were planted with 1 to 100 selected seedlings per family, totalling 810 hybrid seedlings. The field tests were created on the grounds of Semiluksky Experimental Nursery of Central Research Institute of Forest Genetics and Breeding. The soil is a typical chernozem on the watershed slope to the river Veduga.

Trees selected in natural and planted autochthonous stands were used in these series of hybridizations. They were selected for high productivity, frost-resistance, health, and well-formed stems. Pollen from some trees with a pyramidal crown (P. bolleana) was introduced from the Astrakhan Region. Some trees were introduced from the Volgograd (' $P O K$ ') and other Russian regions. The variety ' $P O K^{\prime}$ ' is a hybrid of A.V. Albensky (1959) from crossing $P$. pyramidalis $\times P$. nigra. Aspen pollen was obtained from Romania. In total, 34 parent trees were used in this series. All resulting trees of this series were planted in collection No 2 at spacing of $5 \times 5 \mathrm{~m}$.

3. A collection of aspen hybrids bred by V.P. Petrukhnov in 1980 was planted in 1982 on the grounds of the Semiluksky Experimental Nursery of Central Research Institute of Forest Genetics and Breeding. The soil is a typical chernozem on the watershed slope to the river Veduga. The collection includes nine hybrid families. The number of plants per family ranged from 32 to 168. In all, 1093 seedlings were planted. The parent trees were also selected in natural and planted autochthonous 
stands. Some of them were introduced from the Moscow Region ('P. Yablokovy), Latvia (P. tremuloides), Ukraine (P. bolleana) a. o. The planting space per tree differed, averaging about $9 \mathrm{~m}^{2}$.

4. A collection of poplar hybrids of the subgenus Eupopulus bred by R.P. Tsareva in 1982 was established in 1984 also on the grounds of the Semiluksky Experimental Nursery of Central Research Institute of Forest Genetics and Breeding. The soil is a typical chernozem on the watershed slope to the river Veduga. The collection includes 26 hybrid families with 1 to 25 plants per family. In total, 420 seedlings were planted. In this crossing series, female parent trees were used that had been introduced from the Semiluksky populetum by A.P. Tsarev of P. maximowiczii, P. trichocarpa, 'Pioneer' (hybrid, received by A.S. Yablokov from crossing $P$. pyramidalis $\times$ P. nigra), 'Regenerata, 'I-455', a. o.; male parents were also from that populetum: $P$. suaveolens, 'Brabantica,' 'Newesis' (hybrid, received by P.L. Bogdanov from crossing $P$. canadensis $\times P$. balsamifera), ' $V G t^{\prime}$, a. o. The spacing per tree was $4 \times 4 \mathrm{~m}$.

5. A collection of poplar hybrids of the subgenus Eupopulus Dode, bred by R.P. Tsareva in 1988 was established in 1990 at the Davydovsky Forest Enterprise of the Voronezh Region. The soil is light loam. The collection includes 26 hybrid families with 1 to 108 plants per family. A total of 590 seedlings were planted. The female parent trees originated from Semiluksky populetum of: P. maximowiczii, P. trichocarpa, 'Pioneer,' 'Regenerata'. The male parents were P. pyramidalis, 'POK', E. t. 42-04 (P. balsamifera $\times$ ' $P O K^{\prime}$ bred by A.P. Tsarev), a. o. The trees were spaced $4 \times 4 \mathrm{~m}$.

The hybrids in the collections were inspected and measured periodically. Their health state, frost damages, survival, as well as height, and diameter at $1.3 \mathrm{~m}$ height in older stages were recorded. The volumes of aspens and their hybrids were determined by the tables of A.V. Tyurin (Tyurin et al., 1956). The volumes of other poplars and their hybrids were determined by the tables of Hadži-Georgiev and Goguŝevski (1972). If the dimensions of poplar hybrid trees exceeded the diameters or heights of the tables, the following equation was used:

$$
V=\pi^{*} D^{2} / 4^{*} H^{*} f / 10000 \text {, where: }
$$

$\mathrm{V}$ - Volume of the trunk, $\mathrm{m}^{3}$;

D - Diameter at height of $1.3 \mathrm{~m}, \mathrm{~cm}$;

$\mathrm{H}$-Height of the tree, $\mathrm{m}$;

$f$-form-factor; $f=V / V$, where $V$ ' is the cylinder, the founding of it is cutting area of trees stem at height of $1.3 \mathrm{~m}$ and the height is the height of trees; $f$ for the poplars on average is 0.39 (Houtzagers, 1937).

According to the Council directive 1999/105/EC (Council, 1999) the statistical control for comparison may be the mean characteristics of the testing aggregate. Correspondingly, in each best family, trees were selected which significantly exceeded the respective average of the hybrid families under test (Tables 3, 4).

In early ages (2-5 years old) the best woody plants were selected if their growth rate exceeds the average total growth rate by two standard deviations (P.P. Besschetnov, 1969; N.V. Starova, 1980). But results of such a selection may change with increasing age, even above the age of ten years. Therefore, the selection was done at 11-18 years with the exception of one site where 8 year old trees were selected. In the best group, hybrid trees were selected which had stem volumes exceeding the mean hybrid family dimensions by $30-50 \%$ and more. In each of the best hybrid families 4-5 best trees were selected. They were ranked by growth performance. Rank changes took place during the time of observation. However, these were inside selected groups.

The process of pollination, seed production, seedling rearing, and field testing are separate steps of a breeding cycle. Some results of each of these steps are presented in this publication. Some of the selected hybrid trees were cloned and tested in field experiments in different regions: Voronezh, Tambov, Volgograd, Donetsk a. o., results of which were published earlier (Veresin, 1974; Tsarev \& Tsareva, 1990; Tsarev, 2013a; Tsarev et al., 2014 a. o.).

\section{Results}

Altogether 736 different crosses were realized in the region of which 54,150 hybrid seedlings were obtained, 10,000 by M.M. Veresin, 1,650 by A.P. Tsarev, 2,500 by V.P. Petrukhnov and 40,000 by R.P. Tsareva (Veresin, 1974; Tsarev, Tsareva, 2010). However due to various reasons (incompatibility of parents, mortality, etc.) the number of hybrid seedlings planted in the collections for further testing was much lower. Schemes of some successful crosses in Populus and Eupopulus subgenera are presented in Tables 1, 2.

Table 1

Scheme and number of successful crossings of poplar subgenus Populus (former Leuce Dode)

\begin{tabular}{lcccc}
\hline $\begin{array}{l}\text { Section } \\
\text { and sex }\end{array}$ & $\begin{array}{c}\text { White } \\
\text { poplars, }\end{array}$ & $\begin{array}{c}\text { Aspen, } \\
\text { के }\end{array}$ & $\begin{array}{c}\text { Intersectional } \\
\text { hybrids, ô }\end{array}$ & $\begin{array}{c}\text { Half- } \\
\text { siblings }\end{array}$ \\
\hline White poplars, +9 & 1 & 2 & - & - \\
\hline Aspen, + & 2 & 4 & 1 & 2 \\
\hline $\begin{array}{l}\text { Intersectional } \\
\text { hybrids, }+\end{array}$ & - & 1 & 1 & -
\end{tabular}

Table 2

Scheme and number of successful crossings of poplar subgenus Eupopulus Dode

\begin{tabular}{|c|c|c|c|c|}
\hline $\begin{array}{l}\text { Section } \\
\text { and sex }\end{array}$ & 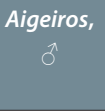 & $\begin{array}{c}\text { Tacamaca, } \\
\delta\end{array}$ & $\begin{array}{c}\text { Intersectional } \\
\text { and complex } \\
\text { hybrids, } \hat{0}\end{array}$ & $\begin{array}{l}\text { Half- } \\
\text { siblings }\end{array}$ \\
\hline Aigeiros, $q$ & 6 & 3 & 10 & 3 \\
\hline Tacamahaca, 웅 & 10 & 2 & 6 & 2 \\
\hline $\begin{array}{l}\text { Intersectional } \\
\text { and complex } \\
\text { hybrids, }+\end{array}$ & - & 1 & 1 & 1 \\
\hline
\end{tabular}


Table 3

Hybrid poplar families and selected best individuals in the field testing collections of the Central Chernozem Region of European Russia

\begin{tabular}{|c|c|c|c|c|c|c|c|c|c|c|}
\hline \multirow{2}{*}{$\begin{array}{l}\text { No } \\
\text { collec- } \\
\text { tions }\end{array}$} & \multirow{2}{*}{ Parents } & \multirow{2}{*}{$\begin{array}{l}\text { Age, } \\
\text { years }\end{array}$} & \multirow{2}{*}{$\begin{array}{c}\text { Num- } \\
\text { ber } \\
\text { trees }\end{array}$} & \multicolumn{3}{|c|}{ Average growth indices, $\bar{X}$} & \multicolumn{3}{|c|}{$\begin{array}{c}\text { Some best individuals selected in hybrid } \\
\text { progenies }\end{array}$} & \multirow{2}{*}{$\begin{array}{l}\text { Authors of } \\
\text { hybrids }\end{array}$} \\
\hline & & & & $\begin{array}{l}\text { diame- } \\
\text { ters, cm }\end{array}$ & $\begin{array}{l}\text { height, } \\
\text { m }\end{array}$ & $\begin{array}{l}\text { volume, } \\
\mathrm{dm}^{3}\end{array}$ & names & $\begin{array}{l}\text { stem volu- } \\
\text { me, } \mathbf{m}^{3}\end{array}$ & $\begin{array}{l}\text { Advantage } \\
\text { over } \bar{X}, \%\end{array}$ & \\
\hline \multirow[t]{2}{*}{1} & alba $\times$ tremula & 20 & 12 & $26.4 \pm 3.04$ & $23.6 \pm 1.01$ & $610 \pm 68^{1}$ & 'Veresin-1' & 1.13 & 85 & $\begin{array}{l}\text { M.M. } \\
\text { Veresin }\end{array}$ \\
\hline & $\begin{array}{l}\text { deltoides } \times \text { balsam- } \\
\text { ifera }^{3}\end{array}$ & 14 & 1 & 23.1 & 15.8 & $290^{2}$ & 'VGt' & 0.29 & -3 & \\
\hline \multirow[t]{3}{*}{2} & -alba $\times$ bolleana & 18 & 5 & $22.9 \pm 2.47$ & $18.3 \pm 0.78$ & $338 \pm 83^{1}$ & 'Veduga', & 0.63 & 85 & A.P. \\
\hline & & & & & & & 'Bolide' & 0.40 & $18^{4}$ & Tsarev \\
\hline & - deltoides $\times$ 'POK' & 18 & 26 & $23.8 \pm 1.31$ & $14.0 \pm 0.50$ & $318 \pm 40^{2}$ & 'Steppe Lada' & 0.87 & 170 & \\
\hline \multirow[t]{4}{*}{3} & $\begin{array}{l}\text { tremula, Obojan } \times \\
\text { canescens }\end{array}$ & 11 & 30 & $13.7 \pm 1.02$ & $11.5 \pm 0.54$ & $110 \pm 14^{1}$ & E.t. $45-11$ & $0.208^{5}$ & $89^{5}$ & $\begin{array}{l}\text { V.P. } \\
\text { Petrukhnov }\end{array}$ \\
\hline & $\begin{array}{l}\text { tremuloides } x \\
\text { tremula(local) }\end{array}$ & 11 & 124 & $13.8 \pm 0.33$ & $12.1 \pm 0.18$ & $97 \pm 5^{1}$ & E.t. $29-05$ & $0.136^{5}$ & $40^{5}$ & \\
\hline & $\begin{array}{l}\text { tremula }\left(X_{2}\right) \times \text { tremula } \\
\text { (local) }\end{array}$ & 11 & 53 & $13.2 \pm 0.4$ & $11.9 \pm 0.22$ & $82 \pm 6^{1}$ & E.t. $44-02$ & $0.112^{5}$ & $37^{5}$ & \\
\hline & $\begin{array}{l}\text { tremula }\left(X_{1}\right) \times \text { tremula } \\
\text { (local) }\end{array}$ & 11 & 148 & $12.3 \pm 0.29$ & $11.3 \pm 0.17$ & $74 \pm 4^{1}$ & E.t. $11-15$ & $0.145^{5}$ & $96^{5}$ & \\
\hline \multirow[t]{2}{*}{4} & 'Pioneer' - half-sibs & 14 & 16 & $17.6 \pm 1.55$ & $13.1 \pm 0.65$ & $180 \pm 40^{2}$ & 'Breeze' & 0.43 & 139 & R.P. \\
\hline & I-455'- half-sib ${ }^{3}$ & 14 & 1 & 26.8 & 17.0 & $412^{2}$ & 'Surprise' & 0.41 & -3 & Tsareva \\
\hline 5 & 'Pioneer' $\times$ '42-04'. & 8 & 3 & $15.5 \pm 0.12$ & $10.8 \pm 055$ & $100 \pm 10$ & E.t. $02-33$ & 0.13 & 30 & $\begin{array}{l}\text { R.P. } \\
\text { Tsareva }\end{array}$ \\
\hline
\end{tabular}

'Determined by Tyurin, 1956

${ }^{2}$ Determined by Hadži-Georgijev \& Gogučsevski

${ }^{3}$ Only one hybrid tree of the family survived which developed as one of best clones in the forest steppe region

${ }^{4}$ Trees selected for pyramidal crown

${ }^{5}$ Productivity rank moved up at higher age (see table 4)

In the collections of the subgenus Populus there are 14 families, and in the collections of the subgenus Eupopulus 45, totalling 59 hybrid families that were successful under the conditions of Central Chernozem Region of European Russia the (Tables 1 and 2).

In the Veresin collection (No 1) the mean stem volume of hybrid family $P$. alba $\times P$. tremula at age 20 years was $0.61 \mathrm{~m}^{3}$ and the elite hybrid seedling 'Voronezh Giant' from crossing P. deltoides $\times P$. balsamifera reached a stem volume of $0.29 \mathrm{~m}^{3}$ by the age of 14 years. The selected individual 'Veresin-l' had a stem volume of $1.13 \mathrm{~m}^{3}$ at 20 years showing an advantage of $85 \%$ over the hybrid families average (Table 3 ).

The mean stem volume of 'Voronezh Giant' at 40 years in Semiluksky populetum was $1.74 \mathrm{~m}^{3}$. Separate trees can be larger (Fig. 1). More detailed data about this populetum is given in Tsarev \& Tsareva (1990), Tsarev (2013a), Tsarev et al. (2014).
The best individual of 'Veresin-1' had a stem volume of about 6 $\mathrm{m}^{3}$ at age 63 years (Table 4, Fig. 2 ).

In collection No 2, two best hybrid families were selected: $P$. alba $\times P$. bolleana and $P$. deltoides $\times$ ' $P O K$ ' The mean stem volume in the first family at age 18 years was $0.34 \mathrm{~m}^{3}$ and in the second $0.32 \mathrm{~m}^{3}$. The best selected individuals of the first hybrid family were the cultivars 'Veduga' and 'Bolide'. 'Veduga' exceeds the mean volume of its hybrid family by $85 \%$. 'Bolide' has not such high growth performance but it has an excellent pyramidal crown and was frost resistant in that region (Figure 3).

The male parent with its pyramidal crown (P. bolleana), introduced from the Astrakhan region, was susceptible to frost, which killed it. In the second hybrid family the cultivar'Steppe Lada' was selected. The growth indices and stem volume growth of these cultivars is shown in Table 4 and Figure 5. The stem volume of the best families in aspen collection No 3 by age 11 years varied from 0.074 to $0.11 \mathrm{~m}^{3}$. In this collection 


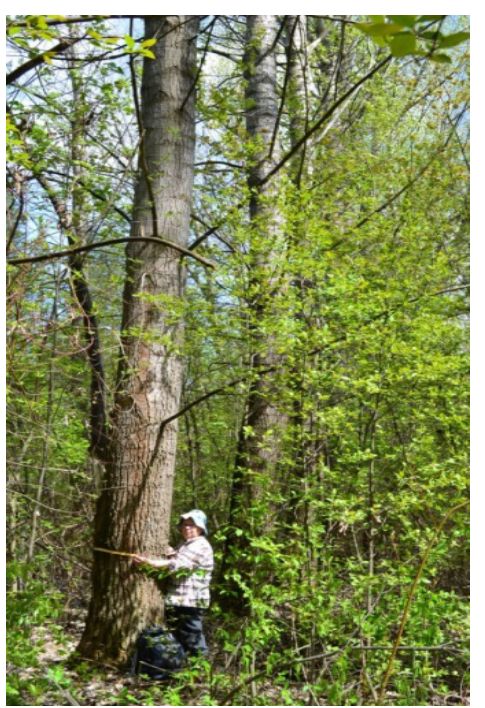

Figure 1

Hybrid poplar 'Voronezh Giant' ('VGt'), which was obtained by M.M. Veresin from crossing $P$. deltoides $X$ $P$. balsamifera. The age of the trees is 39 years. Height is $33 \mathrm{~m}$, diameter $56.7 \mathrm{~cm}$. Voronezh region, Semiluksky Populetum, May 2013. Photo A.P. Tsarev.

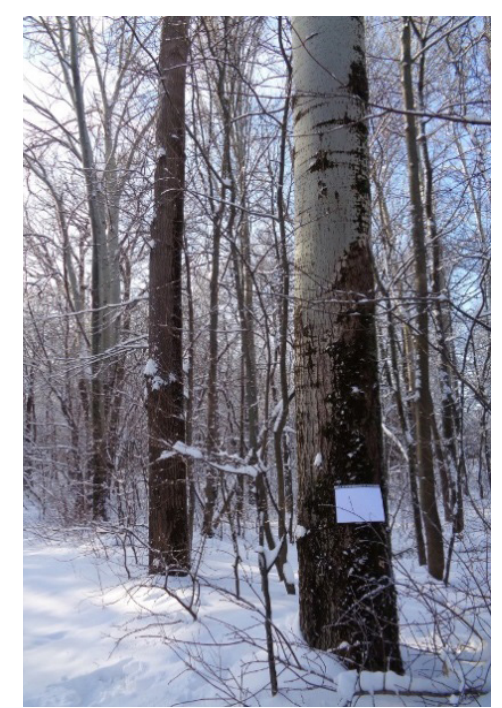

Figure 2

Hybrid poplar 'Veresin-1', which was obtained by M.M. Veresin from crossing $P$. alba $\times$ P. tremula. The age of the trees is 63 years. In the marked tree the height is $40 \mathrm{~m}$, diameter $69.7 \mathrm{~cm}$, volume $5.95 \mathrm{~m}^{3}$. Voronezh, collection No 1, January 2016. Photo A.P. Tsarev.

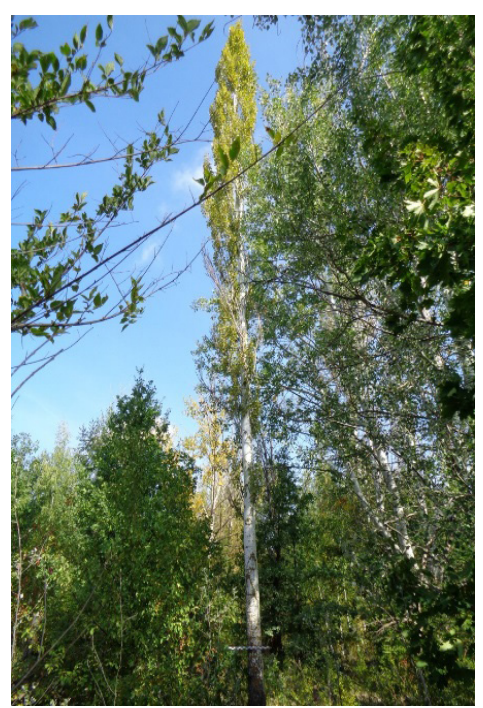

Figure 3

Poplar 'Bolid', which was obtained by A.P. Tsarev from crossing P. alba $\times P$. bolleana. Winter-hardy hybrid with pyramidal crown. The age of tree is 38 years, height is $26 \mathrm{~m}$, diameter $32.2 \mathrm{~cm}$, volume 0.83 $\mathrm{m}^{3}$. Voronezh region, Semiluksky collection of A.P. Tsarev hybrids, August 2015. Photo A.P. Tsarev.

Table 4

Characteristics of some best individuals of hybrid and half-sib cultivars at higher age.

\begin{tabular}{|c|c|c|c|c|c|}
\hline \multirow[t]{2}{*}{ Cultivar name } & \multirow[t]{2}{*}{ Parent trees } & \multirow{2}{*}{$\begin{array}{l}\text { Age, } \\
\text { year }\end{array}$} & \multicolumn{3}{|c|}{ Growth parameters } \\
\hline & & & Diameter, cm & Height, m & Volume, $\mathrm{m}^{3 * *}$ \\
\hline 'Veresin-1' & P. alba $\times$ P. tremula & 63 & 69.7 & 40.0 & 5.95 \\
\hline 'Veduga' & P. alba $\times$ P. bolleana & 38 & 42.4 & 24.7 & 1.36 \\
\hline 'Bolide' & P. alba $\times$ P. bolleana & 38 & 32.2 & 26.0 & 0.83 \\
\hline E.t. $45-11^{*}$ & P. tremula, Obojan $\times$ canescens & 34 & 36.0 & 25.0 & 1.27 \\
\hline E.t. $29-05^{*}$ & P. tremuloides $\times$ P. tremula (local) & 34 & 36.3 & 20.5 & 1.03 \\
\hline E.t. $44-02^{*}$ & P. tremula, $X_{2} \times$ P. tremula (local) & 34 & 35.7 & 21.3 & 1.04 \\
\hline E.t. $11-15^{*}$ & P. tremula $X_{1} \times$ P. tremula (local) & 34 & 40.4 & 21.5 & 1.44 \\
\hline$' V G t^{\prime}$ & P. deltoides $\times$ P. balsamifera & 40 & 42.0 & 32.8 & 1.77 \\
\hline 'Steppe Lada' & P. deltoides $\times P . \times{ }^{\prime} P O K^{\prime}$ & 38 & 47.8 & 25.0 & 1.75 \\
\hline 'Breeze' & P.X 'Pioneer'-half-sib & 32 & 43.0 & 26.0 & 1.47 \\
\hline 'Surprise' & P. 'I-455'- half-sib & 32 & 43.5 & 21.5 & 1.25 \\
\hline E. t. $02-33^{*}$ & 'Pioneer' $\times$ 42-04 & 8 & 17.0 & 11.5 & 0.13 \\
\hline
\end{tabular}

more than 20 best hybrid trees were selected. The stem volumes of some individuals are shown in Tables 3 and 4.

In collection No 4 the half-sibs of the open pollinated 'Pioneer' variety selected by A.S. Yablokov (1956) and one half-sib tree from the Italian cultivar ' $1-455^{\prime}$ ' $P$. $\times$ euramericana (Dode) Guinier cv. ' $1-455^{\prime}$ ') were included. The mean stem volume of the first family at age 14 years was $0.18 \mathrm{~m}^{3}$ (Table 3 ). The best tree of this family was named 'Breeze'. It exceeded with a stem 
volume of $0.43 \mathrm{~m}^{3}$ the mean family stem volume by $139 \%$ at that age. The clone of Italian cultivar ' $1-455^{\prime}$ wasn't frost-resistant and was lost after its introduction to the Voronezh region. But before this, it gave some seeds from which one tree was found to be frost resistant and fast growing. It was named 'Surprise.' At age 14 years its stem volume was $0.41 \mathrm{~m}^{3}$ (Table 3 ) and at age 32 years it was $1.25 \mathrm{~m}^{3}$ (Table 4, Figure 4).

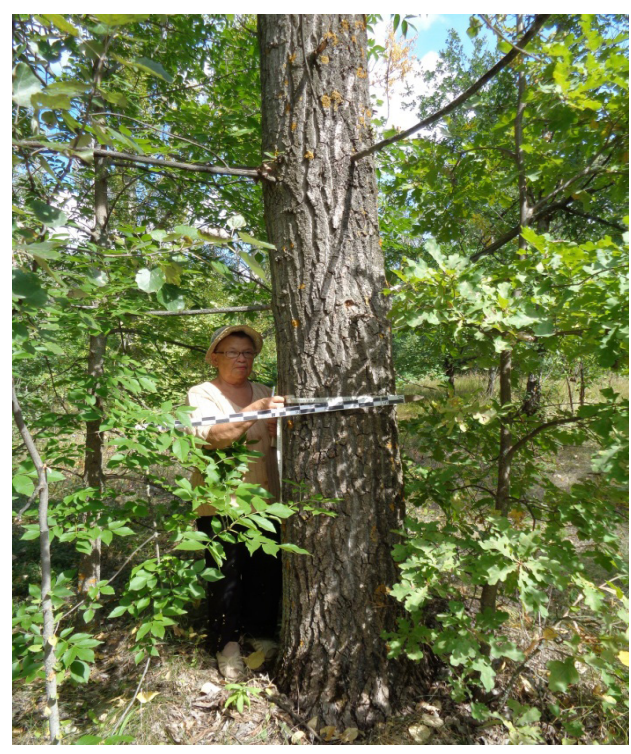

Figure 4

Poplar 'Surprise,', which was received by R.P. Tsareva as half-sib of ' $I-455^{\prime}$ poplar. The age of the tree is 32 years, height $21.5 \mathrm{~m}$, diameter $43.5 \mathrm{~cm}$, volume $1.25 \mathrm{~m}^{3}$, Voronezh region, Semiluksky collection of R.P. Tsareva hybrids, August 2015. Photo A.P. Tsarev.

In collection No 5 only one hybrid family ('Pioneer' $\times$ E. $t$. 42-04) was selected. The E. t. $42-04$ is an A. Tsarev hybrid received from crossing P. balsamifera $\times$ 'POK' (Tsarev, Tsareva, 2010). The mean stem volume of this hybrid family at 8 years was 0.10 $\mathrm{m}^{3}$. The stem volume of the best tree (E. t. 02-33) was $0.13 \mathrm{~m}^{3}$ and exceeded the family mean stem volume by $30 \%$ (Tables 3 , 4).

As can be seen from the Table 3 and 4, the hybrid plants of different ages, growing in different conditions, obtained by different breeders showed for the conditions of the region generally a good growth performance. However, among the families growing under similar conditions and age the hybrids were selected for their favourable characters. They are fast-growing and show better straightness of the trunk, pyramidal crown, high winter hardiness, etc. In total 243 plants were selected (10 plants by M. M. Veresin, 56 A.P. Tsarev, 68 V. P. Petrukhnov, and 109 R.P. Tsareva).

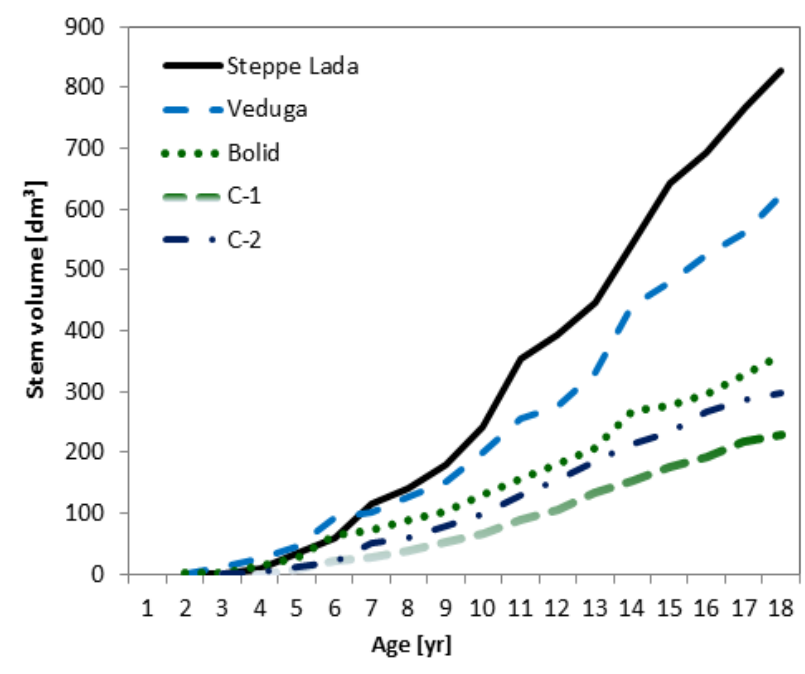

Figure 5

Dynamics of A.P. Tsarev best poplar hybrids volumes, in cubic decimeters $\left(\mathrm{m}^{-3}\right)$. C-1 - control to white poplar cultivars 'Vedu$g a^{\prime}$ and 'Bolid' (mean stem volumes of hybrid family P. alba $\times$ P. tremula); C-2 - control to black poplar cultivar 'Steppe Lada' (mean stem volumes of hybrid family $P$. deltoides $\times$ ' $P O K$ ')

To date 12 promising individuals were selected, including 3 with a P. alba mother, 4 with a P. tremula mother, and 5 resulting from Eupopulus poplars. Among the Eupopulus hybrids, all had a mother of the Aigeiros section including two individuals which were half-sibs of $P$. nigra (Table 4).

The selection rate in different series of crosses differed, but was rather stringent. In the permanent collections of M.M. Veresin two out of fifty hybrid plants were selected. In the surviving plantings of the later crossings A.P. Tsarev selected 3 out of 810 plants; in the third series (hybrids of V.P. Petrukhnov) 4 out of 1093; and in the newest series by R.P. Tsareva from 1010 plants three were selected until now. We have selected a proportion of $0.04,0.003,0.003$ and 0.003 respectively, ranging from 0.3 to $4 \%$.

Some of the best poplar hybrids obtained in the Central Chernozem Region are presented in Fig. 1-4. The growth dynamics of three A. Tsarev hybrids ('Bolide', 'Veduga' and 'Steppe Lada') up to the age of 18 years are shown in Fig. 5.

As can be seen, the height increment of the hybrids in that period of development was high, particularly in 'Steppe Lada'. These hybrid trees were cloned and field tested in the Voronezh and Donetsk Regions. After that, they were presented to the Russian Agronomic Ministry State Sort Commission for patenting. In May 2016 patents and author certificates on these varieties were awarded. 


\section{Discussion}

As shown by the reference data, a huge pool of hybrid poplar cultivars was created internationally. It can include hundreds, and possibly thousands, of hybrid varieties for different regions. Among others, European researchers selected and hybridized best trees in natural and artificial stands. More than ten cultivars were selected by Picarollo and others in Italy (MuhleLarsen, 1970; Sekawin, 1971). 149 clones were selected in Romania by Clonaru a. o. (Ocskay E. A., 1971; Zurma, 1975). 62 aspen plus trees were selected by Zachej in former Czechoslovakia (Zachej, 1961). Nine aspen triploids were selected in Sweden (Nilsson-Ehle, 1936; Tomentorp, 1937; Melander, 1938).

Among trees selected in stands, so-called old cultivars of P. $\times$ euramericana hybrids: 'Robusta,' 'Regenerata', 'Gelrica,' 'Brabantica,' 'Marilandica,' 'Serotina' a. o. need to be mentioned. Furthermore in Italy 'I-214,' II-455,' I-154', I-488', 'I-45/51' a. o. were approved. Until 1973 about 35 P. × euramericana hybrids had been approved (Houtzagers, 1937; Fröhlich, Grosscurth, 1973; Müller, 1974; a. o).

In the next years the cultivar lists increased by new poplar clones which were received on the whole from open pollination. M. Sekawin (1974) recommended in Italy 'I-455, 'I-154', 'I-45/51', ,I-72/58' ('San Martino'), 'I-214,' 'Triplo' ('I 37/61'), 'Boccalairi', 'Gattoni,' 'Harvard' ('I-63/51'), 'Lux' ('I-69/55'), 'Onda' ('I72/51'). In France some tens clones and cultivars were in operational use: 'Fritzy Pauley,' 'Flevo,' 'Onda,' 'Lux,' 'Dorscamp', 'Gigas' 'Magister,' 'White Puatu,' 'Alcinde,' 'San Martino,' 'Agate,' 'Altichiero,' 'Blom,' 'Veronese, 'Guard,' 'Donk' a. o. (FAO,1979; Barneoud, Bonduelle, 1979).

In Germany, recommended cultivars of $P$. deltoides were: 'Lincoln', 'Marquette', and 'Peoria'. Fröhlich and Weisberger (1974) recommended among old cultivars: 'Flachslanden', 'Gelrica,' 'Grandis,', 'Harff,', 'Heidemij', 'Löns,', 'Neupotz,' 'Ostia,' 'Robusta'; from new cultivars they recommended: 'Allenstein', 'Bietigheim,' 'Büchig,' 'Dolomite,' 'Lampertheim,' 'Lingenfeld,' 'Rintheim'; from Italian cultivars they recommended: 'I-214' and 'Jacometty-78 $B$ '; from balsam poplars: 'Brühl', 'Muhle-Larsen', as well as 'Scott Pauley'; and from inter- and intrasectional hybrids: 'Androscoggin', 'Oxford', and 'Rochester.' In Germany different hybridization experiments by controlled crosses of aspen, P. nigra, and balsam poplars were carried out (Melchior, 1985; Janßen et al. 2012; Liesebach et al., 2012 a. o.).

In North and South America, Asia, New Zealand a. o. places also big efforts were taken in introducing and using the wellestablished cultivars and selecting spontaneous hybrids as well as carrying out controlled hybridizations (Muhle Larsen, 1970; Zsuffa,1975; Poplars..., 1979; Stanton et al., 2014; FAO, 2012; а. о.).

Until 1979 more than 100 cultivars were in world-wide use of (FAO, 1979). Unfortunately, most of these cultivars and hybrids (excluding aspen and balsam hybrids) aren't resistance to Russian winter frosts. Therefore, Russian researchers are forced to breed suitable cultivars tolerating the prevailing frosts.

One could conclude that it is not necessary to spend more on hybridization work as sufficient cultivars are already available. Especially, because new genetic methods are being developed to increase the diversity of the existing forms of plants and creation of genotypes with desired traits.

However, looking at the small global resource of commercially valuable hybrids (FAO, 1979; Stanton et al., 2014) it is only a drop in the ocean of possible phenotypic diversity. In accordance with the Chromosomal Theory of Inheritance of 1903 by Sutton and Boveri, the number of possible phenotypes of two parents is expressed by a value equal to $2^{n}$, where $n$ is the haploid number of chromosomes in the parents. Thus, the number of possible phenotypically different plants, only one parental pair of poplars can generate is $2^{19}$ or 524288 phenotypes.

And this is only one pair of the same species without mutation, polyploidization, transgenesis and other external influences and without regard to the number of species of poplar and countless number of pairs in intraspecific and interspecific crosses. It turns out that without any interference, the gene pool of poplars can reproduce billions of different phenotypes. The task of tree breeders is to select them or try to reproduce them by artificial means.

However, each specific context requires differently cultivated plants. Moreover, in the initial works on hybridization for practical purposes, breeders tried to select individual superior varieties or cultivars for different conditions and purposes.

It was later revealed that in order to avoid significant losses due to unforeseen biotic and abiotic influences more than one cultivar with close economic qualities, but different in genetic composition are required. To ensure such diversity, constant efforts are needed to upgrade and improve existing sets of genotypes.

In addition, as in some other regions of the world, Russia needs poplar varieties that are resistant to winter frosts. If, in the warmer regions of the world, such peculiarities are playing a smaller role, further north this becomes crucial. This breeding goal, along with growth performance, quality, and others, was a priority in the case of hybridization in the conditions of the Central Chernozem Region. The fact, that many selected hybrid plants have reached a considerable age demonstrates the accomplishment of the task.

It is interesting to note that for gaining hybrids of higher quality also a higher intensity of selection is required. Theoretically, this means that the smaller the proportion of plants selected from their population, the higher the coefficient of selection (Zobel, Talbert, 1984). In this case, the proportion of selected individuals of the population will be equal to about 0.05 .

In the analyzed experiments, this proportion was generally smaller. However, if this requirement applies to individual hybrid families, the intensity of the selected proportion from the population can be much bigger. For example the hybrid 'Voronezh Giant' ('VGt') was selected by M.M. Veresin in a single copy of the family. But it was the best among the many hybrids of the other families. When testing it in the Central Chernozem Region it showed outstanding growth characteristics (Fig. 1).

Additionally to the systematic work in producing a vast number of hybrid offspring, sometimes the factor of "unpredictability" or "luck" is included. In this case, research of the 
genetics department of the Central Research Institute of Forest Genetics and Breeding in 1971 showed that ' $V G t^{\prime}$ contains the majority of cells with a triploid set of chromosomes. Their number was $78.4 \%$, while the diploid and aneuploidy proportion was $19.6 \%$, and tetraploid $1.9 \%$ (Veresin, 1974).

Another phenomenon was shown in a series of crosses by R.P. Tsareva. The four to date selected best phenotypes were half-sibs of $P$. nigra (Table. 4). Among them are the cultivars 'Breeze' and 'Surprise'. Special attention is drawn to the latter which is derived from the Italian cultivar ' I - 455.' Generally, the experiments in the Central Chernozem Region showed that Italian poplars are not adapted to the harsh climate. But the individual of ' $I-455$ ' obtained from Ukraine managed to give seed before its complete freezing. From these seeds half-sibs were obtained, from which this seedling was selected. The hybrid 'Surprise' is distinctly more resistant to winter frost than the female parent tree (Fig. 4).

In 2015, three cultivars 'Bolid,' 'Veduga' and 'Steppe Lada' were transmitted to the state registration authorities of hybrid varieties and were approved. The first two differ in their pyramidal crown and the third in high productivity. All three cultivars are resistant to winter frost in the Central Chernozem Region. Cultivar 'Bolid' which has a cypress-like pyramidal crown is presented in Fig. 3.

It should be noted that in the Russian State Register until 2015 only three cultivars of poplars from all 13 cultivars of forest trees and 17750 cultivars of various agricultural, fruit and ornamental crops are listed [State register...., 2015]. This list has now been extended by three new A. Tsarev cultivars 'Veduga', 'Bolid' and 'Steppe Lada' to be used in the Central Chernozem Region.

\section{Conclusions}

Despite the emergence of various genetic techniques to create new genotypes with desirable properties (mutagenesis, polyploidy, transgenesis etc.) hybridization is a successful breeding method resulting in genotypes with a new combination of genes important for poplar culture.

- Among the woody plants in the temperate zone, the most successful breeding results were obtained in poplar. The number of practically important hybrids has increased exponentially, if counting from the mid-forties of the twentieth century with 83 important hybrid poplar cultivars (excluding the USSR). However, this is only a little fraction of the possible phenotypic diversity in the genus Populus.

- In the Central Chernozem Region by efforts of several generations of researchers 736 crossing variants of poplars of the Populus and Eupopulus subgenera were realized resulting in 54 thousand hybrid seedlings. After a first selection in the seed bed about three thousand seedlings were field tested under different site conditions.

- There was a periodic selection in the field tests throughout the ontogeny of plants after phenotypic evaluation of growth performance, disease and frost resistance, stem quality and other economically important traits. Initially, 243 individuals were selected. With further selection steps to date 12 cultivars were selected among the best suited hybrid plants.

- Not all of the global pool of poplar hybrids currently has found practical application. Of the tens and hundreds of thousands of hybrids produced internationally, approval and official registration was given only to a few dozen cultivars. In Russia only three varieties were registered officially. Now, this list of poplar cultivars has been extended by three varieties of A.P. Tsarev ('Veduga,' 'Bolid' and 'Steppe Lada'). Some hybrids and original forms are preserved in the collections of the gene pool, and can find application in the future.

- In order to mitigate the risks of unforeseen calamities, injury or other adverse factors, not only one but several cultivars are needed for sustainable afforestations with close economic value, but different genetic composition. Given this, poplar breeding is continuing to be of great importance in both, the immediate and the long term future.

\section{Acknowledgement}

The authors would like to thank Vadim Tsarev for his help to collecting and processing poplar hybrid data and also for first translation editing of the Russian version of the manuscript. The authors also extend thanks to the collective of formerly Central Research Institute of Forest Genetics and Breeding Semiluksky Experimental Nursery and Davydovsky Forest Enterprise for nursing and protecting the poplar hybrid collections. The manuscript was prepared 2015-2016 with the support of German Federal Food and Agricultural Ministry, "MaRussiA" project (grant 68706, BLE).

\section{References}

Albensky AV (1959) Selection of tree species and seed production. Moscow-Leningrad: Goslesbumizdat, 306 p. (In Russian).

Barneoud C, Bonduelle P (1979) La culture du peuplier. Paris: Assotiation foret-cellulose (AFOCEL), 274 p., ISBN 1-85166-494-7

Berezin AM (1939) Description of hybrids of poplars. In: proceedings of VNIILM; Vol 5. Moscow: VNIILM, pp 61-80. (In Russian).

Besschetnov PP (1969) Poplar: culture and selection. Alma-Ata: Kainar, 156 p. (In Russian).

Bogdanov PL (1965) Poplars and their culture. Moscow: Lesnaja promyshlennost, 104 p. (In Russian).

Chmielewski W (1969) Mieszancowe topole hodowli institute badawczego lesnictwa i ich wstepna ocena. Poland: Prace Institut badawczego lesnictwa. No. $372.113 \mathrm{~s}$

Council directive (1999) /105/EC of 22 December 1999: On the marketing of forest reproductive material. In Official Journal of the European Communities / Legislation. V 43. L.11. 15 January 2000, pp 17-40.

FAO (1979) Poplars and willows in wood production and land use. FAO Forestry series, Rome. No. 10, 328 p., ISBN 92-5-100500-1

FAO (2012) Synthesis of Country Progress Report. Activities Related to Poplar and Willow Cultivation and Utilization- 2008 through 2011. October 2012 Forest Assessment, Management and Conservation Division Forestry Department. Working Paper IPC/12E FAO, Rome, Italy. International Poplar Commission, 24th Session, Dehradun, India, 30 October-2 November 2012: Improving Lives with Poplars and Willows, $104 \mathrm{p}$

Fröhlich HJ, Grosscurth W (1973) Züchtung, Anbau und Leistung der Pappeln. Frankfurt am Main: Sauerlander, 267 p. ISBN 3793902501 
Fröhlich HJ, Weisberger H (1974) Moguenosti i granice gajenja topola u Saveznoj Republici Nemackoj. Topola 18 (100-101):45-48.

Heimburger C (1936) Report of poplar hybridization. Reprinted from the Forestry chronicle 12 (3):285-290. https://doi.org/10.5558/tfc12285-3

Hadži-Georgijev K, Gogučsevski M (1972) Dvolazne tabele mass za topola klona Populus euramericana cv. I-214 u gevgeliskom području. Topola 16 (90): 2529.

Houtzagers G (1937) Het Geslacht Populus Verband met zijn Beteekenis voor de Houtteelt (The genus populus and its significance in silviculture). Vageningen: H. Veenman \& Zonen, $266 \mathrm{p}$.

Ivannikov SP (1959) Selection of aspen in the forest on the rapidity of growth, resistance to rot and wood quality. In: The experience and achievements in forest species. Moscow: VNIILM Works, Vol. 38. pp 63 - 124 (In Russian).

Janßen A, Fehrenz S, Fey-Wagner C, Hüller W (2012) Züchtung von Schwarz- und Balsampappeln für den Kurzumtrieb. In: Züchtung und Ertragleistung schnellwachsender Baumarten in Kurzumtrieb: Erkenntnisse aus drei Jahren FastWOOD, ProLog und Weidenzüchtung, Fachtagung vom 21. Bis 22.09.2011 in Hann. Münden, Beitrage aus der Nordwestdeutschen Forstlichen Versuchsanstalt, Band 8, Universitätsverlag Göttingen. pp 33-54, ISBN 978-3-86395-070-5

Kazartsev IA (1956) Breeding of new breeds of drought - and salt-tolerant poplars. In: Bulletin of scientific and technical information VNIILM. Moscow: VNIILM. No. 1, pp 15-17 (In Russian).

Konovalov NA (1963) Breeding of fast-growing tree species in the Middle Urals. Forestry. (7): 55-58. (In Russian).

Lemoin M (1973) Amelioration des peupliers de la section Leuce sur la sols hydromorphes. These doct. ing. Univ. Nancy. 115 p.

Liesebach M, Schneck V, Wolf H (2012) Züchtung von Aspen für den Kurzumtrieb. In: Züchtung und Ertragleistung schnellwachsender Baumarten in Kurzumtrieb: Erkenntnisse aus drei Jahren FastWOOD, ProLog und Weidenzüchtung, Fachtagung vom 21. bis 22.09.2011 in Hann. Münden, Beitrage aus der Nordwestdeutschen Forstlichen Versuchsanstalt, Band 8, Universitätsverlag Göttingen. pp. 71-90, ISBN 978-3-86395-070-5

Melander I (1938) A new giant Populus tremula in Norrbotten. Hereditas 24

(1-2):189-194. https://doi.org/10.1111/j.1601-5223.1938.tb03213.x

Melchior GH (1985) Züchtung von Aspen und Hybridaspen und ihre Perspectiven für die Praxis. Allgemeine Forst- und Jagdzeitung 156:112-122.

Muhle-Larsen C (1970) Recent advances in poplar breeding. In International review of forestry research, V 3 . New-York - London: Academic Press, pp 1-67. https://doi.org/10.1016/b978-0-12-365503-5.50007-4

Müller R (1974) Die Pappel-Altsorten (Section Aigeiros) in der Bundesrepublik Deutschland. Mitt. Deutsch. Dendrol. Ges. (67):14-23.

Nilsson-Ehle H (1936) Über eine in der Natur gefundene Gigas Form von Populus tremula. Hereditas 21 (2-3): 379-382. https://doi.org/10.1111/j.1601-5223.1936.tb03205.x

Ocskay S., Clonaru A, Dumitru G, Milea J (1971) Cercetari referitoare la ameliorarea plopilor si salcilor de interes economic. Bucuresti: s. n., 129 p.

Ozolin GP (1962) Poplar Breeding in Uzbekistan. Tashkent: RIO of Uzbek SSR Agriculture Ministry, 198 p. (In Russian).

Pauley SS (1949) Forest-Tree Genetics Research: Populus L. Economic botany 3 (2):299 - 330. https://doi.org/10.1007/bf02859100

Petrukhnov VP (1988) Hybridization of Aspen in Central Chernozem Region. In: Hybridization of Forest Trees. Voronezh: Edition of Central Research Institute of Forest Genetics and Breeding, pp 101-106. (In Russian).

Pyatnitsky SS (1961) Practical Work on Forest Tree Breeding. Moscow: Publishing house of agricultural literature, magazines and posters, 271 p. (In Russian).

Sekawin M (1960) Quelques observations sur la selection des peupliers de la section Leuce en Italie. In: Seatl Fifth World Forestry Congress Proceedings, pp 806-807.

Sekawin M (1971) Alcuni nuovi cloni di pioppo selesionati in Italia. Estrato da Cellulosa e Carta (5) 3-32.

Sekawin M (1974) Prisnati klonovi topola u Italiji. Topola 49 (1):31-34

Stanton B (2012) The genus Populus in North America: an overview of plantation operations and domestication approaches, In: Züchtung und Ertragleistung schnellwachsender Baumarten in Kurzumtrieb: Erkenntnisse aus drei Jahren FastWOOD, ProLog und Weidenzüchtung, Fachtagung vom 21. Bis 22.09.2011 in Hann. Münden, Beitrage aus der Nordwestdeutschen Forstlichen Versuchsanstalt, Band 8, Universitätsverlag Göttingen. pp 21-31. ISBN 978-3-86395-070-5
Stanton BJ, Serapiglia MJ, Smart LB (2014) The Domestication and Conservation of Populus and Salix Genetic Resources. In: Isebrands J S, Richardson J (eds) Poplars and Willows - Trees for Society and the Environment. Published by The Food and Agriculture Organization of the United Nations and $C A B I, p p$ 124-199, ISBN 978-1-78064-108-9 (CABI), ISBN 978-92-5- 107185-4 (FAO). https://doi.org/10.1079/9781780641089.0124

Starova NV (1980) Breeding of willows. Moscow: Lesnaja Promyshlennost, 207 p. (In Russian).

Steenackers V (1969) L'etat actuel de la selection et de la creation des clones de peupliers resistant aux diverse maladies. In: Second World Consultation on Forest Tree Breeding, Washington, D.C., U.S.A., 7-16 August 1969; v.2: Production and use of high-yielding varieties; World Consultation on Forest Tree Breeding, 2, Washington, DC (USA), 7-16 Aug 1969 / FAO, Rome (Italy). Forestry Dept.; Vienna: International Union of Forestry Research Organizations, pp 1087-1107

Stout AB, McKee R, Schreiner EJ (1927) The breeding of forest trees for pulp wood. Journal of the New York Botanical Garden. 28 (327):49-63.

Stout AB, Schreiner EJ (1933) Results of a project in hybridizing poplars. Hereditas (24):217-229. https://doi.org/10.1093/oxfordjournals.jhered.a103780

The state register of selection achievements, admitted to use (2015) V 1. Varieties of plants (Official publication). Moscow: Federal state institution „State Commission of Russian Federation for testing and protection of selection achievements" of the Russian Agriculture Ministry, 468 p. (In Russian).

Tomentorp G (1937) The chromosome numbers of two new giant Populus tremula. Botaniska Notiser: $285-290$

Tsarev AP (1984) Modification of the detached branches cultivation method and the duration of generative organs development in the case of hybridization in the genus Populus L. In Mashkin SI (editorship) Mutagenesis and hybridization in plant breeding: Proc. articles. Voronezh: Publishing house of Voronezh State University, pp 96-99. (In Russian).

Tsarev AP (2013 a) Growth and breeding of aspen in Russia. Silvae Genetica 62 (4-5):153-160.

Tsarev AP (2013 b) Programmes of Forest Tree Breeding (in Russia and abroad). Moscow: Moscow State Forest University Edition, 164 p, ISBN 978-5-81350592-8 (In Russian).

Tsarev AP, Pogiba SP, Laur N V (2014) Breeding of Forest and Ornamental Tree Plants. Moscow: Moscow State Forest University Edition, 553 p, ISBN 978-58135-0605-5(In Russian).

Tsarev AP, Tsareva RP (1990) Poplar breeding in the regions of temperate climate of the USSR. In: Proceeding of the XIX IUFRO World Congress, 5-11 August 1990. Division 2 Montreal, pp 28-37.

Tsarev AP, Tsareva RP (2010) Poplar hybridization and initial testing of hybrid progenies in the Central Chernozem Region. In: Genetics, breeding, seed production and reproduction of tree species. Proceedings of All-Russian scientific-practical conference with international participation, devoted to the 100 anniversary from the birthday of Professor Veresin Mikhail Mikhailovich. Voronezh: Voronezh state forestry engineering academy, pp $125-$ 138, ISBN 978-5-7994-0373-7 (In Russian).

Tsareva RP (1988) Hybridization of Eupopulus poplars in the Voronezh region. In: Hybridization of forest tree species. Voronezh: Science annals of Research Institute of Forest Genetics and Breeding, pp 49 - 61. (In Russian).

Tyurin AV, Voropanov PV, Naumenko IM (1956) Forest auxiliary book (on forest inventory). Edited by A. V. TYRIN. 2nd edition. Moscow - Leningrad: Goslesbumizdat, 532 p. (In Russian).

Tyszkiewicz S, Chmielewski W (1961) Hybridizacija topoli. Prace Institutu badawczego lesnictwa. Warszawa: Panstwowe wydawnictwo rolnicze i lesne, $190 \mathrm{~s}$.

Veresin MM (1974) New hybrid poplars for forest plantations and landscape gardening. Forestry information (6):14-15. (In Russian).

Veresin MM, Tsarev AP (1974) To poplar field testing results in Voronezh region. In: Genetics, breeding, and introduction of forest tree species. Voronezh: All-Russian Research Institute of Forestry and Forestry Mechanization edition, pp 31-42. (In Russian).

Wettstein W von (1941) Wuchssteigerung durch Kombinationszüchtung und Chromosomenvermehrung. Forstarchiv (17): 80-83.

Wettstein W von (1942) Möglichkeiten neuer Züchtung der Kreuzung nach Ökotypen. Der Züchter 14 (12):282-285. https://doi.org/10.1007/bf01812449

Wright JW (1962) Genetics of forest tree improvement. Forestry and Forest Products Study. Rome: FAO (16). 227 p. 
Wühlisch G von (2006) Ergebnisse der Züchtung von Pappeln und Aspen in Großhansdorf. Perspektiven für die energie- und Rohstofferzeugung. Vortr. Pflanzenzüchtung 70:157-172.

Wuehlisch G von (2010) Growth Performance of F1-Hybrids, Backcrossed Hybrids and F2-Hybrids of Populus tremula and Populus tremuloides. In Fifth Intern. Poplar Symp. Poplars and willows: from research models to multipurpose trees for a bio-based society. Orvieto, Italy. Sept. 20-25 2010. Book of Abstracts, pp 37.

Yablokov AS (1956) Pyramidal poplars. Moscow-Leningrad: Goslesbumizdat, 58 p. (In Russian).

Yablokov AS (1963) Raising and breeding of healthy aspen. Moscow: Goslesbumizdat, 442 p. (In Russian).

Yanchevsky K (1904) On the germination peculiarities of aspen seeds and of some willow species. In: Proceeding of Imperial Forest Institute. Saint-Petersburg Forest Institute (11):269 - 274. (In Russian).

Zachej S (1961) Vyberove stromy osiky. Lesn. Časop. 7 (5): 319-330.

Zobel B, Talbert J (1984) Applied Forest Tree Improvement. John Wiley \& Sons, New York.

Zsuffa L (1975) Some problems of hybrid poplar selection and management in Ontario. Forestry Chron. LI (6): 240-242. https://doi.org/10.5558/tfc51240-6

Zsuffa L, Sennerby-Forsse L, Weissgerber H, Hall RB (1993) Strategies for clonal forestry with poplars, aspens, willows. In: Ahuja, M R, Libby W J (eds.) Clonal Forestry II: Conservation and Application. Berlin: Springer, pp 91-119. https://doi.org/10.1007/978-3-642-84813-1 5

Zurma T (1975) O kulturi topola i vrba u Socijalistickoj Republici Rumuniji. Topola 19 (107-108): 63-71. 